Volume 11(1), 2017

Page: 15-38

\title{
Comparative Analysis of Agricultural Financing in Some Countries
}

\author{
Inten Meutia ${ }^{1}$, Mohamad Adam ${ }^{2}$, Titin Vegirawati ${ }^{3}$
}

\begin{abstract}
This study aims to find the similarities and differences in financing practices that occurred in The Agricultural Bank of Iran, China, Sudan, Malaysia and Baitul Maal wat Tamwil in Indonesia, and to obtain best farmers and agricultural enterpreneurs financing practices. This study used qualitative approach. Case study is selected as strategy in this research. The method of data collecting is documentation. Data is obtained from websites and annual reports of each agricultural bank. The data collected is the bank's policy data on financing distributed to farmers and agricultural enterpreneurs. Agricultural Bank of China uses interest based product. This bank offer flexible loan and flexible time of payment. Agricultural bank in Iran and Sudan offer partnership and constant profit financing products to farmers. Malaysia and BMT Sidogiri in Indonesia offer constant profit contract. But their financing contract, tawarruq and Bay al Wafa are still controversial contracts. Observed agricultural banks have been using sharia priciples, except for Agricultural Bank of China. The financing product that has been used since the time of the Prophet has been applied by the agricultural banks. However, there are still controversial financing used by these banks.
\end{abstract}

Keywords: Agricultural Finance, Agricultural Bank, Partnership Contract

Abstrak. Penelitian ini bertujuan untuk menemukan persamaan dan perbedaan dalam praktik pembiayaan yang terjadi di Bank Pertanian Iran, China, Sudan, Malaysia dan Baitul Maal wat Tamwil di Indonesia, dan mendapatkan praktik pembiayaan terbaik bagi petani dan pengusaha sektor pertanian. Penelitian ini menggunakan pendekatan kualitatif. Studi kasus dipilih sebagai strategi dalam penelitian ini. Metode pengumpulan data adalah dokumentasi. Data diperoleh dari situs web dan laporan tahunan masing-masing bank pertanian mengenai kebijakan bank tentang pembiayaan yang disalurkan kepada petani dan pengusaha pertanian. Bank Pertanian China menggunakan produk pembiayaan berbasis bunga. Bank ini menawarkan pinjaman dan waktu pembayaran yang fleksibel. Produk pembiayaan yang ditawarkan oleh Bank Pertanian di Iran dan Sudan adalah produk pembiayaan kemitraan dan produk pembiayaan dengan keuntungan konstan kepada petani. Malaysia dan BMT Sidogiri di Indonesia menawarkan produk pembiayaan dengan kontrak keuntungan konstan. Namun kontrak pembiayaan yang mereka salurkan, tawarruq dan bay al wafa masih menjadi kontrak pembiayaan yang kontroversial. Bank pertanian yang diamati telah menggunakan prinsip syariah, kecuali Bank Pertanian China. Produk pembiayaan yang telah digunakan sejak zaman Nabi telah diterapkan oleh bank-bank pertanian. Namun, masih ada pembiayaan kontroversial yang digunakan oleh bank-bank tersebut.

Kata kunci: Pembiayaan Pertanian, Bank Pertanian, Kontrak Kerjasama

${ }^{1}$ Lecturer at Sriwijaya University | inten26@yahoo.com

2 Lecturer at Sriwijaya University | mr_adam2406@yahoo.com

${ }^{3}$ Lecturer at Sriwijaya University and PhD student at IBA University | titinvegirawati@gmail.com 


\section{Introduction}

The government should pay attention to agricultural sector, because this sector can speed up economic development of the country (Omorogiuwa, Zivkovic, and Ademoh, 2014). Sanrego and Rusydiana (2009) have explained important roles of the agricultural sector to Indonesia's economic development: (1) the agricultural sector produces food and nutrient sources of the Indonesian population, (2) agricultural sector absorbs a large quantity of labor (Ahangar, Ganie, and Padder, 2013). In early 2017, the labor absorbed in this industry was 31.86 percent (BPS, February 2017), (3) the agricultural sector contributes 13 percent to GDP at the end of 2016 and (4) Agricultural output is industrial raw materials and export commodities. Thus agricultural output can be a source of foreign exchange.

It is not easy to develop agricultural sector. Farmers must face various risks along agricultural chain. These agricultural risks consist of production risk, technological risk, pest and disease risk, price risk or market changes, the risk of changes in government policy and financial risk, climate change risk, and personal risk. These risks become sources of uncertainty of farmers' incomes (Ridhwan, Aziz and Yusoff, 2013; Shafiai, 2017).

Various risks that hinder the growth of agricultural products are not able to demolish the spirit of agricultural entrepreneurs. The farmers who were the respondents of research stated that they consistently continued this effort. For them, agricultural projects are the major source of their income. They want their farmland, will become their next generation farmland. They also consider other realistic and economic reasons. This important reason is high demand for agricultural products (Ridhwan, Aziz, and Yusoff, 2013).

Despite the lack of capital, agriculture and farming industries are still reluctant to involve banks to meet funding needs. Farmers prefer informal financing such as landlords and families rather than by financing their 
agricultural projects to banks. Such financing options are motivated by the desire of farmers to avoid banks' complicated bureaucracies and high interest rates.

The attention of conventional banking and Islamic banking to agricultural entrepreneurs is still very low. Total agricultural credit that has been given to farmers is only 14.85 percent of total bank credit at the end of 2016. One of the reasons why banks have not provided funds to agricultural entrepreneurs intensively is agricultural risks. The fickle weather causes the price of crops to fluctuate, so farmers often pay late or even fail to pay installment debt to the bank. Agricultural sector's non-performing loan of 3.32 is higher than the banking NPL of only 3.18 (Kompas, 2017).

The government can support agricultural entrepreneurs through government policies. One area of policy that should be generated by the government is the funding policy. Organization for Economic Co-Operation Development, abbreviated as OECD (2015), explained that the government should ensure there is a policy to improve the financial market so as to facilitate funding for investment in the agricultural sector and increase the size of farming. Organizations that promote policies to improve the economy and social welfare also ask the government to regulate the amount of credit and interest rates in order to encourage the growth of the agricultural sector.

In order to realize a financing product in favor of farmers, banks must understand the pattern of this farming business. The income earning pattern of farmers and agricultural entrepreneurs is different from the income patterns of other business activities that can earn periodically. Their income is earned according to their harvest time (Asaad, 2011). Other problems facing farmers are related to uncontrolled nature risks, causing the number of crops to fluctuate. Banks should implement profit sharing systems, not interest rate systems. 
The principle of risk sharing is a suitable principle to farmers who always face the risk of farming (Khasanah et al., 2013). By sharing risks, Islamic banks can stimulate economic growth and entrepreneurial activity to address poverty and inequalities, ensure financial and social stability, and promote the development of equitable human resources (Islamic Development Bank, 2015). Islamic banks and farmers share their income and loss fairly.

Islamic Agricultural Bank, which uses risk sharing principle in partnership contract and sales-based has various types of banking products. It should design banking finance product especially for agricultural entrepreneurship with due regard to the nature of agribusinesses.

Efforts to obtain financing products that best suit the agricultural business can be done by conducting comparative studies. Some countries have made concrete efforts to help agricultural business actors. Iran, China, Sudan, and Malaysia have established special banks for agricultural entrepreneur. Although Indonesia is an agricultural country, until now it has not had agricultural bank. However, concrete efforts to assist farmers have been done by financial institutions such as those conducted by Baitul Maal wat Tamwil Sidogiri in Surabaya East Java.

\section{Literature Review}

The success of farmers can be seen from performance of agricultural growth. The performance of agricultural growth is characterized by an increase in agricultural production, increased cropping intensity, rapid spread of seeds and increased farmer income (Bardhan and Mookherjee, 2011). In addition, it is also determined by the ability of farmers to face various risks.

The wealth of natural resources, the vast and fertile land are not enough to make successful farmers. They still need plant seeds, fertilizers, pesticides and agricultural machinery as inputs in producing agricultural produce. Farmers must also enter the industrial networks of agricultural products 
managers, and wholesalers to be able to obtain competitive prices for their crops (Young-kon, 2013).

To be successful, farmers must also be able to control and deal with various risks. Ridhwan, Aziz, and Yusoff (2014) observed production risk, technological risk, market risk, pests attack risk, animal and plant risk, changes of government policy, financial risk, weather risk, personal risk and natural risk. Their results stated that farmers had some experience and knowledge about risks advantage and disadvantage. Farmers need a lot of funds to overcome them. They are also looking for investors who willing to share the risk, even if only half.

Some farmers do not have strong capital to finance all of their agricultural project activities until harvest time arrives. One of the main sources of capital is the yield of last year's harvest. Farmers usually have to sell the crops as soon as possible to earn cash, so often crop must be sold at a low price. Furthermore, farmers do not earn enough money either for household consumption or to increase the amount of agricultural production (Ahmed et al., 2012).

Government and banks together facilitate farmers in producing various agricultural products in order to maintain national food security. The government should encourage banks to provide special financing products for farmers and agricultural entrepreneurs. Wagan et al. (2016) have proven that lending to farmers can increase farmers' income and living standards. However, so far there are still many poor farmers (Kaleem and Wajid, 2009).

Before deciding best financing product for farmers, banks have to understand the nature of agricultural business. This nature effects farmers' financial behavior. Ahmed et al. (2012) described three sectors of agricultural produce as a source of income for farmers, namely seasonal crops returns, perennial crops returns and livestock returns. Seasonal crop is an important annually produced crop that can contribute to the sustainability of farming and farmer income. Livestock also provides income to farmers on a regular basis. 
While perennial crop is a plant that must be financed several years before giving a significant result.

According to Ahmed et al. (2012) on seasonal crops or food crops, farmers go through three periods: surplus, balance and deficit period. In the surplus period, farmers are in post-harvest period. Farmers have a lot of money coming from their crops. The money they have used to pay their debts to the informal lenders, who are also the buyers of their crops. The balance period occur when they plan and consume their crops. While difficult times are in the period of deficit. At this time the farmers are not earning and spending a lot. They should finance the establishment of farm crops and household consumption. At this time farmers need financing assistance from lenders.

Perennial crop is a significant source of income for farmers who can save farmers from poverty. However a major obstacle to farmers in realizing perennial crops is the high cost of establishing plantations and the recurrent cost of financing crops for several years that are required before yield and revenues obtained. For poor farmers these costs may be out of reach and cannot survive without external financing support. Costs incurred during the process of establishing new plantation can be seen in the following figure.

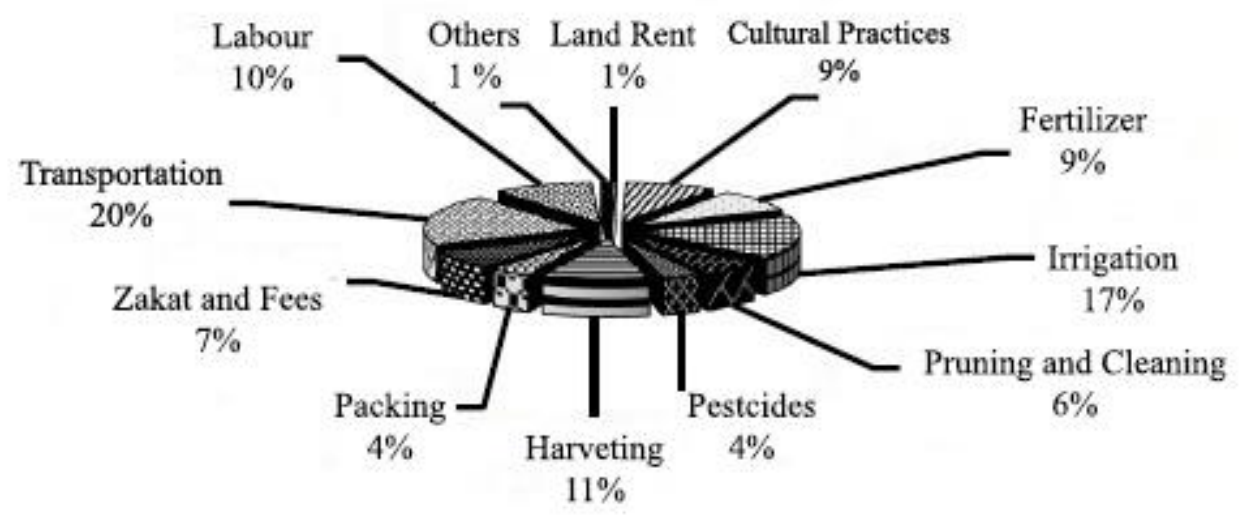

Figure 1. Percentage Share Of Variable Cost For Perennial Crops Source: Ahmed et al. (2012) 
The behavior of farmers' debt payments differs from other financing. Kaleem and Wajid (2009) stated from the results of their research on the debt repayment behavior of farmers in Pakistan. Their results stated that 46.5 percent of the total respondents, paying the debt after the harvest has been sold, 45.5 percent said the farmers who responded to the debt when they get money from other sources, the remaining 8.5 percent said they would pay the debt in accordance with the agreement.

Islamic banking is a reliable alternative banking industry for farmers and government to solve various problems in agriculture sector. These banks are responsible for social welfare and commitment to religion in an effort to achieve the Islamic economic goals of social justice, equitable distribution of income and welfare and promote economic growth (Dusuki, 2008). Financing products issued by Islamic banking have risk sharing principles. This principle is highly understood by farmers as having to deal with various risks (Ridhwan et al., 2014). Financing products issued by Islamic banking allows farmers to choose the option of payment at once or installments.

To achieve the economic goals of Islam as rahmatan lil alamin, various products have been issued Islamic banking with the principle of risk sharing and no exploitation. Islamic banking financing products can be grouped into three methods: partnership method, selling method or sell-based instrument and lease or ijära method.

\section{Islamic Banking Financing Product: Using Partnership Method}

Financing using partnership method is often also called equity based financing (Ismal, 2009). According Fasih (2012) Islamic Banking operates three types of partnership, partnership between two or more persons who agree to invest together for profit. Each partner agrees to share profit or loss from their business. Partnership like this is called mushāraka (Arshad, 2010). The second form of partnership is mudhārabah. In a mudhārabah partnership, a person who provides 100 percent of the capital is referred shähibul mal party, while other 
who run the business by applying their expertise and strength is called mudhārib (Suryawardani and Hasbi, 2013). The third type is a mix of mudhārabah and mushāraka. In this type someone who has invested also apply his skills. Both partners are free to choose an agreed percentage of earnings, while for passive partners, profit sharing depends only on the percentage of their investment.

\section{Islamic Banking Financing Product: Using The Principle Of Sale (Sale-Based Instrument)}

One of the muamalah based on Islamic principles is a sales contract known as muräbahah. Muräbahah contract is a sale contract between the bank and its client on a commodity. Bank decide selling price of commodity from cost plus margin in advance (Ismal, 2014). Muräbaha contract can only be used if the client needs a commodity. This contract is constituted by the rule mentioned in the Qur'an, but God permitted trade. Increase in value should only be on sale not on debt (Zandi, Ariffin, and Shahabi, 2012).

Other muamalah based on Islamic principles is salam and istisna. Valid criteria of sales are commodity owned by the seller physically and constructively (Ehsan and Shahzad, 2015). Nevertheless, there are two sales contracts that Islam permits without following the above sales contract principles. The contracts are bay al-salam and bay istisna. Bay al-salam is a buy and sell contract between two parties, the buyer makes a payment at the time the transaction is made, and the seller suspends the delivery of goods on a future date (Kaleem and Wajid, 2009). For this reason Rasulullah SAW agreed with the terms of this sales contract, the seller must explain the weight, size and time of delivery of goods sold concretely (Ehsan and Shahzad, 2015). Salam was used during the time of the Prophet Muhammad and Caliph Abu Bakar Siddiq to sell wheat, dried dates and dry grapes. Salam transaction is used for foodstuff sales transactions (Ehsan and Shahzad, 2015). 
The third muamalah form of buying and selling contract is istisna. Istisna is a buy and sell contract, in which the buyer pays the goods ordered for production. The goods produced must conform to the contract specifications that have been made between the seller and the buyer (Rouf, 2013). The istisna contract is usually used to finance the construction of buildings, or industrial equipment (Mohsin, 2005).

\section{Islamic Banking Financing Product: Using Lease Principle (Ijārah)}

Ijārah is muamalah in the form of rent. Ijārah can be interpreted as having the benefit of the asset, by earning some money from the person who hired it. Ijārah seems similar to the lease transaction in conventional financial institutions. But ijārah does not use two transactions at once. On the ijārah agreement, the bank will perform two separate transactions. The first bank purchases the commodity to the seller. Then the bank handed over the purchased commodity to the buyer with the lease agreement. The bank allows the buyer to acquire ownership if the buyer has completed all lease payments and residual value (Siddiqi, 2008).

\section{Method}

Research design of this paper is qualitative approach. Qualitative research strategy which used in this paper is case study. Researchers chose four different agricultural banks in different countries. These agricultural banks has operated for more than 40 years. In Indonesia, there is no agricultural bank. Baitul Maal wat Tamwil Sidogiri is selected to be object of this research, because this baitul maal has served farmer financing need. The secondary data was collected through document analysis of the agricultural banking, Islamic Agricultural Banking and Islamic cooperative websites and annual reports in 2015 and 2016. The purpose of this research is to compare agricultural mechanism of financing in Iran, China, Sudan, Malaysia and Indonesia and 
find out the similarities and the differences. The other purpose is to find out best product practice to finance farmer and agricultural entrepreneur.

\section{Result and Discussion}

\section{Agriculture Financing in Iran}

The Iranian government established the Keshavarzi Bank or the Agricultural Bank of Iran, which started its operation in 1933. The bank's objective is to increase agricultural production, strengthen the agricultural sector so that food self-sufficiency that includes basic commodities and livestock can be realized and expand the export market agriculture. This bank and all banking activities in Iran must use and adhere to Islamic principles.

Banking activity consists of activities to obtain financial resources and provide financing. Keshavarzi Bank financial resources are obtained from customers using Islamic products such as qard al hasanah and deposits without interest rate. While financing is provided in the form of partnership without interest rate. Partner profit sharing settlement is based on real rate of return after project completion. Partnership is done by fulfilling agriculture facilities needed by farmers.

Financing facilities are provided in the form of partnership contracts and constant-profit contracts. In the partnership contracts, the bank provides all or part of the funds needed to run a project. The profits to be gained will be distributed according to the agreement. Partnerships related to the agricultural sector are (1) Mudhārabah, partnerships between banks and customers, which banks provide capital while customers provide expertise and management. Management of banks and customers has determined profit sharing in advance. (2) Muzara'a, is a contract that allows banks to lease agricultural land and divide the profits earned. The Bank also provides seeds of plants, fertilizing, irrigation, pesticides, transportation and others. The Bank has the right to design the contract of muzara'a. (3) Musaqat is a similar contract of 
muzara' $a$, but in this case bank provides the garden and hand it over to the farmer for a certain period, then the bank gets the profit share (Keshavarzi Bank, 2015).

Constant-profit contracts are contracts in which the bank provides some funds to finance certain economic activities. On this contract the bank determines the profit in advance. The financing is a contract (1) Hire-Purchase is a contract that allows the bank to buy and rent equipment, machinery or buildings. At the end of the lease period, the bank as leesee deposits the item to the lessor. Banks are eager to help the agricultural sector. This is evident at the level of profit sharing for farming to the lowest bank compared with other types of businesses that is only at 6 to 8 percent. (2) Jo'aleh is a service contract, in which one of the parties between the bank and the customer offers a service to obtain a commission (Ashraf and Giashi, 2011) (3) Installment sale, a financing in which the bank sends goods to the customer for a certain price, then partial or total diamoritisir, and on the due date with the same or not the same installment. (4) Forward sale, is a contract in which the bank buys goods produced by the seller in cash, but the goods will be received later (Keshavarzi Bank, 2015).

\section{Agriculture Financing in China}

Agricultural Bank of China is a Chinese agricultural bank established in 1951. The bank provides its loan products to farmers. The loan product provided to farmers as individuals and farmers working capital products. They offer two cards namely Kins Farmers Benefit Card and Farmer Benefit Credit Card. Kins Farmers Benefit Card is used for cash deposits, withdrawals, transfers and repayments, consumption and financing. While Farmer Benefit Credit Card is a debit card as well as credit card given to farmers as individuals. Farmers can save and earn interest. With this card, the farmer can withdraw the loan within the loan limit that the bank has approved. The highest credit limit is RMB 300,000. Card users can pay their loan bank that forms, provides, 
supervises and coordinates credit for agricultural projects in Malaysia. The mission of Agro Bank is to provide holistic financing that follows market demand and market needs, through wise financial management to agricultural, micro, small and medium entrepreneurs. In 1996 Agro Bank offered Islamic products, and became a full fledge Islamic Bank on 2015.

Agro bank provides financing to farmers with several purposes. The first funding is intended to replant or expand or oil palm plantations. Financing is given to small planters with a financing limit of RM 10,000 per hectare. Time period financing for up to ten years, with an expected profit rate of 8.85 percent annually paid monthly. This financing uses tawarruq transaction. The second financing product is given to farmers who grow whenever they want, can be paid by installment or paid at once. Banks charge interest on loans calculated in accordance with actual business day.

Regarding rural production and operations, Agricultural Bank of China also provides micro finance to farming families. The loan is given by the bank to the farmer by pledging warranty, mortgage or collateral with the farmer's household. The loan is designed flexibly, able to borrow at any time on an approved credit line and can repay the loan whenever the farmer is willing to pay. The Bank also lends to the approved credit line at the same time, the farmer can pay at once or in installments. Interest will be calculated according to actual working day.

Loans are also offered by Agricultural Bank of China to agricultural entrepreneurs in the form of corporate products. This product consists of working capital loan products, revolving line of credit and commodity market formulation. Working capital loans are given to agricultural entrepreneurs as working capital during the production or operation process. Loan term of less than one year is classified as short-term loan to medium-term loan for three years. Revolving line of credit is a loan that has been determined ceiling, and can be used up to the loan ceiling. Loans can also be used for international 
trade. This credit is a short-term credit usually one year. The third credit granted to corporations is The Loan for County-level Commodity Circulation Market Construction. This loan is a loan related to the acquisition of assets granted to the project owner for market commodities covering the needs of warehouses and shops.

\section{Agriculture Financing in Agriculture Bank of Sudan}

Agriculture Bank of Sudan was established in 1957 and started its operations in 1959. The strategic objective of this bank establishment is to mobilize the national economy that relies on agricultural production, whether from crops or from livestock and fishery and agriculture-related industries. To achieve this strategic objective, the Agriculture Bank of Sudan sets various targets: (1) developing the agricultural sector and other sectors by channeling financial, service, extension, training, marketing and warehousing finance to competent people. (2) increasing agricultural production and realizing village development. (3) create a series of national food security strategies.

Agricultural Bank of Sudan provides various financing facilities to help development of agricultural sector. Banks may provide funds for wetland, plantation or livestock. In addition, the bank also encourages investment in the form of joint plant and animal agro processing by providing capital, funding input production inputs, providing various storage services and marketing services to the export level.

Financing given to farmers and breeders is done by using various contracts based on Islamic sharia. Contracts that can be selected are salam, al muzara' $a$, istisna, rent ending with ownership, muräbaha, Installment sale and al mushārakah. In order to support various contracts purely, Agricultural Bank of Sudan has infrastructure such as warehouses in rural areas scattered in various regions of Sudan. The bank also has grain storage warehouses such as wheat. The bank also has the Center for Remote Sensing and Geographic Information Systems (GIS) used to follow the Bank's financial operations to reduce risk, 
make production estimates and provide information for food security, making storage, marketing and export planning based on the estimated value of production and providing relevant information such as insurance companies.

\section{Agriculture Financing In Malaysia Agricultural Bank}

Agro Bank formerly known as Bank Pertanian Malaysia was established on the decision of parliament on 1 September 1969, and operated on January 1 , 1970. It is thisrice, where farmers have received certificates provided by government agencies. The amount of financing given to farmers amounted to RM 1,000 to RM 50,000. The term of the loan is six months which can be extended up to five years. Profit rate is 3.25\% per season. This financing uses tawarruq transaction. Tawarruq transaction is a sale and purchase transaction involving a third party. Someone buys the goods in installments sales contract from seller. Then the buyer sells the that goods in cash to get cash, through an intermediary bank. This financing form is still in the form of debt financing. Until now the bank has never used a profit-based financing and loss sharing.

\section{Agriculture Financing in Indonesia}

Sharia Savings and Loan Cooperative Baitul Maal wat Tamwil Integrated Joint Venture Sidogiri abbreviated to cooperative BMT UGT Sidogiri began operations in 2000 in Surabaya. The purpose of BMT UGT Sidogiri Cooperative establishment is to develop of people's economy based on Islamic sharia and the realization of ta'awun culture in the goodness and piety in the field of social economy. To achieve these goals the cooperative conducts its economic activities with the STAF culture (Siddiq, Tabligh, Amanah and Fatonah).

One of the financing products of Cooperative BMT UGT Sidogiri is UGT Agricultural Capital Barokah (UGT MPB). This financing is a financing facility for venture capital to overcome member difficulties and the need for 
agricultural capital, as well as to help secure the certainty of the sale of their produce. The financing of barokah agricultural capital funds the farmers by using murabahah schemes, ijārah parallel agreement and bay al wafa. Muräbahah scheme is used for purchase transactions of seeds, fertilizers and / or medicines. The bank will sell seeds, fertilizers and medicines to farmers by adding a mark up on the purchase price of the product. To fund lease of labor, or machinery and seed purchases, fertilizers and or medicines, cooperatives can also use parallel ijārah and bay al wafa contracts. Parallel ijārah is a lease agreement between a bank and a member. Banks lease goods to customers, in which the goods belong to third parties who expect compensation for the goods leased. While bay al wafa is contracts for members who need money can sell their goods to the bank by agreement when he can return the price of the goods, then he can buy back the goods. The bank may obtain income from the lease of the goods under an ijärah agreement.

In order to secure cooperative funds, financing can only be given to productive farming and to qualified and experienced farmers. The financing period is only six months and can be extended up to twice. Until now financing can only be given with a ceiling of fifty million rupiah.

\section{Discussion}

Agriculture is the most important sector of each countries in the world, because the product of the agricultural sector can maintain national food security, ensuring the availability of industrial raw materials and able to contribute to the country's foreign exchange in large numbers. Nevertheless, the development of the agricultural sector has encountered many barriers to agricultural risks.

Three financing principles used by agricultural banks and related financial institutions of the five countries studied are interest-based, partnership contract and constant-profit contract. China uses interest-based 
contracts, while Iran and Sudan use partnership contract and constant-profit contracts, while Malaysia and Indonesia use constant-profit contracts only.

Of these three financing principles, there is one financing that fits perfectly with the nature of the agricultural enterprise. The agricultural business faces various risks that hamper agricultural production growth. Farmers are hoping that there is someone or institution willing to share the business risk even if only half (Kaleem and Wajid, 2009). The farmers' expectations can be met from banks that distribute financing under the partnership contract principle. Under the partnership contract principle, the bank obtains a share of the profits and incurs a portion of the loss that may occur.

In using partnership contracts, agricultural banks in Iran and Sudan, using various contracts. Iran uses the mudhärabah, muzara'a and musaqah contracts. While Sudan uses muzara'a and mushärakah contract banks can provide financing as support action for agricultural entrepreneurs and farmers. Financing facilities are used by agricultural entrepreneurs and farmers to cover the costs of various agricultural operations and inputs, which they can not afford to pay for. Financing support is expected to stimulate the development of agricultural products on an ongoing basis.

Some countries have operated agricultural banks. Each bank in particular country has its own superiority. Some agricultural banks use similar principles, and the other uses unique principles. All principles used are adapted to religion, norm and culture from each country.

In China, Agricultural Bank is a conventional bank. Of course the bank imposes interest expense on farmers' credit. Farmers must pay interest expense at the interest rate multiplied by the number of days of actual use of credit. The lowest interest rate charged is between 4.50 percent to 6.15 percent.

Agricultural Bank of China facilitates agricultural entrepreneurs and farmers with flexible credit. Farmers can borrow whenever they need and pay 
whenever they have enough money to pay. Farmers must pay the installment or credit to pay all at once. Such credit is suitable given to farmers, because it contains the time of applying for a loan and the flexibility of time to pay. So farmers can borrow whenever they need funds to finance their agricultural projects and pay their liabilities after they get money from the sale of the harvest.

Credit facilities from agricultural banks in China charge interest on the value of debt. Farmers must pay the debt plus interest debt on loan value and loan term. Either the farmer succeeds in obtaining the harvest or experiencing crop failure. Interest arrears can become bigger and burdensome to farmers.

Unlike in China, Agricultural Bank in Iran, Sudan, Malaysia and Cooperative BMTUGT Sidogiri in Indonesia have implemented Islamic banking system. These banks do not charge interest on the financing provided, but use the principle of risk sharing and mark up on the value of the products sold. This principle is a fairer principle because there is no element of bank exploitation of farmers.

Agricultural Bank of Iran provides financing based on partnership contracts and constant-profit contracts or sale-based contracts. Based on the partnership contracts, banks can distribute financing through mudhārabah, muzara' $a$ and musaqat contracts. While in constant-profit contracts, banks can provide financing through hire purchase, installment sale, forward sale and jo'aleh contracts.

In line with Agricultural Bank of Iran, Agricultural Bank of Sudan also provides financing facilities in partnership contracts and constant-profit contracts. In partnership contracts, this bank distributes financing through muzara'a and mushärakah. While in constant-profit contracts banks can distribute financing through ishtisna contract, rent ending with ownership, murābaha, installment sale, and salam.

Agricultural Bank of Malaysia does not provide financing through partnership contracts. The bank only distributes finance based on constant- 
profit contracts, through a tawarruq agreement. Farmers or agricultural entrepreneurships have to pay their liabilities in installment.

Indonesia is an agricultural country, unfortunately until now this country does not have an agricultural bank. However, real efforts to assist farmers have been done by the Sidogiri BMT UGT Cooperative in Surabaya, Indonesia. In providing financing, Cooperative BMT UGT Sidogiri does not use a partnership contract. They use financing with constant-profit contracts through murābaha, parallel ijärah, and bay al wafa contract.

Mudhärabah and mushārakah are partnership contracts that use profit and loss sharing principle. These contracts are unique contract, not similar with conventional bank contract. the difficulty of finding the right client is the reason this rarity is used in Islamic banks. Muzara' $a$ and musaqah's contracts used by agricultural banks in Iran and Sudan are two commonly used contracts in agricultural partnership. In general, muzara' a contract is a contract between landowner and farmer, where landowners submit their land to farmer to plant, maintain, and harvest for a specific joint share of crops. Then musaqah is a contract between landowners of some trees and farmers who water and care for the shade trees and share their harvest between them. Experts state that these contracts were partnership and permissible. This partnership is considered by lawyers to be similar to the mudāraba contract (Shafiai and Moi, 2015).

This contract is a contract on the agricultural sector that provides many benefits to the community. This agreement has grown a helpful attitude between landowners and farmers. This contract also reduces unemployment and increases agricultural production, and as a positive impact this contract can boost national economic growth (Ngasifudin, 2016). Banks should be equipped with systems that can support banks to run partnership contracts, as has been done in Sudan. 
Besides using partnership contracts, agricultural banks in Iran, Sudan, Malysia and Indonesia use constant-profit contracts. Akad used Agricultural Bank of Iran or often called Bank Keshavarzi with this principle is hire purchase, installment sale, forward sale and jo' aleh. Agricultural bank of Sudan using salam, istisna, rent ending with ownership, muräbaha and installment sale contract. Agricultural Bank of Malaysia using tawarruq contract, while Cooperative BMT UGT Sidogiri in Indonesia using muräbaha, parallel ijārah and bay al wafa.

Various contracts used in some countries have similarities, such as hire purchase at Agricultural Bank of Iran, with rent ending with ownership at Agricultural Bank of Sudan. But unlike the parallel ijārah on the cooperative BMT UGT in Indonesia. The installment sale agreement on Agricultural Bank of Iran and Sudan is in a line with the muräbaha agreement on Agricultural Bank of Sudan and in Indonesia. The forward sale agreement on Agricultural Bank of Iran is similar to salam's contract on the Agricultural Bank of Sudan. Two unusual contracts applied in other countries, but applied, namely tawarruq contracts in Malaysia and bay al wafa contracts applied in Indonesia.

Hire purchase and rent ending with ownership is the same contract. This contract represents a lease agreement, in which the lessor gives the option to the lessee to purchase at the end of the lease term. Murābaha and installment sale contracts are contracts by using a constant-profit contract or sales-based contract. This contract is a sale and purchase in which the seller will sell a product with a cost plus marked up which is usually paid in installments. But there is a weakness in this contract. Banks often determine the rate of return according to the prevailing interest rate (Zandi et al., 2012).

Forward sale or salam contract is a contract in which the buyer of agricultural produce pays first full of agricultural products, while the delivery of agricultural products is delayed until the harvest is completed. This salam comtract is very suitable for agricultural enterprise and farmer, because the delivery of the harvest is done after the farmers get their crops. (Kaleem and 
Wajid, 2009). The benefits of this salam contracts can be obtained by both parties. Farmers get cash flow at the right time, when they need money to carry out their farm operations. Buyers get a low price because they have bought agricultural produce faster (Nasution, 2016).

Salam is a contract based on the sales recommended by Rasulullah SAW. One of the Prophet's hadiths explains if someone involves salam and pays the price of the goods to be shipped later, then the parties involved should mention the weight, size and date of delivery. In connection with this hadith, the companion of Rasulullah SAW, Abu Bakar Siddiq RA explained that this contract is used to sell agricultural products such as wheat, barley, dried grapes and dried dates.

Tawarruq is a rarely used contract in various countries. Tawarruq is a controversial contract that tends to be close to the practice of usury (Suharto, 2013). This contract is deemed similar to the inah contract, but involves a third party. Basically, tawarruq is a sharia based contract to obtain cash. The allowable tawarruq is a classic tawarruq, in which the buyer buys a product by delay, and sells it back in cash to a third party for a lower price. The product owner must obtain cash from a third party who buys the item in cash (Ahmad et al., 2017). This tawarruq contract is valid only if the buyer of the product sold by the owner of the product is a third party.

Bay al wafa is a contract that still contains controversy. The Hanbali and Maliki schools tend to ban the use of these products because these financing products combine three contracts at once in bay or sale, rahn or deposit and ijarah or rent (Kudus and Naghfir, 2017). The same thing is also expressed by (Al-Masri, 2006), that renting goods to the owner, promise sale is only a means to justify the loan usury.

Different opinions expressed by some moslem jurists and scholars. They had seen bay al wafa was an ordinary sales contract. Some other experts consider the contract as a covenant of rahn, but the mortgaged person gives permission 
to enjoy the results of the mortgaged goods. The moslem jurists and scholars opinion is corroborated by the opinion of the Hanafi school, which states that bay al wafa is a useful thing to avoid usury.

\section{Conclusion}

The agricultural banks and cooperative baitul maal wat tamwil studied provide unique financing specifically for farmers and agricultural entrepreneurs. These banks and cooperatives have understood the nature of the agricultural business. Agricultural business covers agricultural risks, while the income is obtained by farmers after the harvest is sold. The nature of this business has become the attention of agricultural banks in distributing financing. To accommodate the nature of this agricultural business, some agricultural banks have offered partnership financing, where banks receive a share of profits and are willing to bear the risk of bank losses. Agricultural bank of Sudan and Agricultural Bank of Iran have distributed this financing. Agricultural bank distribute financing when farmers need financing, and offer flexible repayment schedules of time and payment amounts. Agricultural bank of China has implemented such financing. Farmers can pay their debt after the harvest is sold. The form of financing offered is salam. Agricultural Bank of Sudan and Agricultural Bank of Iran have implemented such financing. Nevertheless, some banks are still applying controversial products in the view of shariah namely tawarruq agreement and bay al wafa.

\section{References}

Ahangar, G. B., Ganie, A. H., and Padder, M. J. (2013). A study on institutional credit to agriculture sector in India. International Journal of Current Research and Academic Review. 1(4): 72-80.

Ahmad, E. F., Shihama, M., Tarmizi, N. A. bt M., Jibril, S. M., Djama, S. I., and Muneeza, A. (2017). Tawarruq as a Product for Financing within the Islamic Banking System: A Case Study of Malaysian Islamic Banking System. International Journal of Management and Applied Research. 4(1): 31-43. 
Ahmed, E. A., Faki, H. H. M., and Hussein, A. (2012). Role of Agricultural Finance in Producing Food Crops. International Journal of Agriculture and Forestry. 2(2): 10-15. Available at: http:// doi.org/10.5923/j.ijaf.20120202.03

Al-Masri, R. Y. (2006). Renting an Item to Who Sold It Is It Different from Bay Al-Wafa Contract? Islamic Economic Journal. 19(2): 39-42.

Arshad, N. C. (2010). Shariah Parameters for Musharakah Contract: A Comment . International Journal of Business and Social Science. 1(1): 145162.

Asaad, M. (2011). Peningkatan Peranan Perbankan Syariah untuk Pembiayaan Usaha Pertanian. Miqod. 35(1): 113-127.

Ashraf, S. H., and Giashi, A. A. (2011). Islamic Banking in Iran - Progress and challenges. Kuwait Chapter of Arabian Journal of Business and Management Review. 1(2): 31-44.

Bardhan, P., and Mookherjee, D. (2011). Subsidized Farm Input Programs and Agricultural Performance: A Farm-Level Analysis of West Bengal's Green Revolution, 1982-1995. American Economic Journal: Applied Economics, 3(October). 186-214.

Dusuki, A. W. (2008). Understanding the objectives of Islamic banking: a survey of stakeholders' perspectives. International Journal of Islamic and Middle Eastern Finance and Management. 1(2): 132-148. Available at: http:// doi.org/10.1108/17538390810880982

Ehsan, A., and Shahzad, M. A. (2015). Bay Salam: A Proposed Model for Sharia Compliant Agriculture Financing. Business and Economic Review. 7(1): 67-80.

Fasih, F. (2012). Inclusive growth in India through Islamic banking. In International Conference on Emerging Economies - Prospects and Challenges. 37: 97-110. Available at: http://doi.org/10.1016/j.sbspro.2012.03.278

Ismal, R. (2009). Assessing Moral Hazard Problem in Murabahah Financing. Journal of Islamic Economics, Banking and Finance. 5(2): 101-112.

Ismal, R. (2014). Assessing The Gold Murabahah in Islamic Banking. International Journal of Commerce and Management. 24(4): 367-382. Available at: http://doi.org/10.1108/IJCoMA-05-2012-0034

Kaleem, A. and Wajid. (2009). Application of Islamic Banking Instrument ( Bai Salam ) for Agriculture Financing in Pakistan. Available at: http:// doi.org/10.1108/00070700910941471

Khasanah, U. et al. (2013). The Practice of Profit and Loss Sharing System For Rice Farmers in East Java, Indonesia. International Research Journal of 
Finance and Economics. 9(3): 1-7.

Kudus, and Naghfir. (2017). Efektivitas Akad Pembiayaan Bai Al Wafa Pada Baitul Maal Wat Tamwil. Arena Hukum, 10(1): 1-19.

Mohsin, M. I. A. (2005). The Practice Of Islamic Banking System In Sudan. Journal of Economic Cooperation. 4(26): 27-50.

Nasution, Z. (2016). Model Pembiayaan Syariah untuk Sektor Pertanian. Jurnal DINAR Ekonomi Syariah. 1(1): 1-12.

Ngasifudin, M. (2016). Aplikasi Muzara'ah Dalam Perbankan Syariah. Jurnal Ekonomi Syariah Indonesia. 6(1): 38-44.

Omorogiuwa, O., Zivkovic, J., and Ademoh, F. (2014). The Role Of Agriculture in The Economic Development Of Nigeria RIA Omorogbe Omorogiuwa. European Scientific Journal. 10(4): 133-147.

Ridhwan, M., Aziz, A., and Yusoff, M. M. (2013). Financing for Agro Projects in Islamic Banks. In International Conference on Agriculture and Biotechnology. 60: 14-18. Available at: http:// doi.org/10.7763/IPCBEE.

Ridhwan, M., Aziz, A., and Yusoff, M. M. (2014). Identifying Risks of Financing for Agro Projects in Islamic Banks. International Journal of Technical Research and Applications. 4(4): 29-33.

Rouf, K. A. (2013). Islamic Sharia-based Group Microlending Initiative and Implementation Trajectory Experience in Kandahar. Journal Research in Peace, Gender and Development. 3(8): 133-141.

Sanrego, Y. D., and Rusydiana, A. S. (2009). Peran Perbankan Syariah dalam Mendorong Agro Investasi. Jurnal Keuangan Dan Perbankan. 13(2): 311324.

Shafiai, M. H. M., and Moi, M. R. (2015). Fitting Islamic Financial Contracts in Developing Agricultural Land. Global Journal Al-Thaqafah. 5(1): 43-49.

Shafiai, M. hakimi M. (2017). Financial Problems among Farmers in Malaysia: Islamic Agricultural Finance as A Possible Solution. Asian Social Science. 11(4): 1-16. Available at: http://doi.org/10.5539/ass.v11n4p1

Siddiqui, A. (2008). Financial Contracts, Risk and Performance of Islamic Banking. Managerial Finance. 34(10): 680-694. Available at: http://doi.org/10.1108/03074350810891001

Suharto, U. (2013). Contentious Sales in Islamic Banking and Finance: Analysis on Their Proximity to Riba. IKIM Journal of Islam and The Contemporary World. 6: 55-82.

Suryawardani, B., and Hasbi, H. (2013). Ther Performance of Islamic Banking on Mudharabah Financing In Indonesia. In Brawijaya International 
Conference on Accounting and Business. 29-30.

Wagan, S. A., Rahman, A., Shuanxi, X., and Noonari, S. (2016). Significance of Agricultural Finance in Agricultural and Rural Development of Pakistan " A Case Study of Qambar Shahdadkot District." European Journal of Business and Management. 8(16): 64-70.

Young-kon, K. (2013). An Integrated Value Chain Finance in Agriculture: Experience of Agricultural Cooperatives in Korea. In Presented at the Policy Dialogue Forum on Value Chain Finance in Agriculture. 3-5.

Zandi, G., Ariffin, N. M., and Shahabi, A. (2012). Some issues on Murabahah practices in Iran and Malaysian Islamic banks. African Journal of Business Management. 6(24): 7066-7073. Available at: http:// doi.org/10.5897/ AJBM11.2859 